\title{
Mycobacterium bovis identification by a molecular method from post-mortem inspected cattle obtained in abattoirs of Mato Grosso do Sul, Brazil
}

\section{Cristina Pires de Araújo ${ }^{++}$, Clarice Q ueico Fugimura Leite, Karina Andrade de Prince, Klaudia dos Santos Gonçalves Jorge*, Ana Luiza Alves Rosa 0 sório*/+}

\author{
Faculdade de Ciências Farmacêuticas, Universidade Estadual Paulista Júlio de Mesquita Filho, Araraquara, SP, Brasil \\ *Universidade Federal de Mato Grosso do Sul, Cidade Universitária, 79070-900 Campo Grande, MS, Brasil
}

\begin{abstract}
The presence of Mycobacterium bovis in bovine carcasses with lesions suggestive of tuberculosis was evaluated. Seventy-two carcass samples were selected during slaughter inspection procedures in abattoirs in the state of Mato Grosso do Sul, Brazil. Seventeen (23.6\%) of samples showed colonies suggestive of mycobacteria that were confirmed to be acid-fast bacilli by Ziehl-Neelsen staining. Polymerase chain reaction (PCR) using primers specific for M. bovis identified M. bovis in $13(76.5 \%)$ isolates. The PCR-restriction enzyme pattern analysis using gene encoding for the 65-kDa protein and two restriction enzymes identified the remaining four isolates that were represented by two $\mathrm{M}$. tuberculosis complex and two nontuberculous mycobacteria. The results are indicative of infection of slaughter cattle by M. bovis and other mycobacteria in the state of Mato Grosso do Sul.
\end{abstract}

Key words: Mycobacterium bovis - nontuberculous mycobacteria - polymerase chain reaction - PCR-restriction enzyme pattern analysis - cattle - post-mortem inspection - abattoirs

Tuberculosis plays a central role in public health and animal health because of its severity in humans, in addition to the economic losses related to affected herds (Rodriguez et al. 1999). According to WHO (1993), infection with Mycobacterium bovis is responsible for about $5 \%$ of human tuberculosis ( $\mathrm{Tb}$ ) cases in Brazil, suggesting the importance of better control of transmission from cattle to man (Parreiras et al. 2004). In Brazil, the prevalence of the disease in bovines was estimated at $1.3 \%$ from 1989 to 1998 (Brasil 2003). In the southwestern state of Mato Grosso do Sul, from 1974 to 1979, Schenk and Schenk (1982) observed prevalence of lesions suggestive of bovine $\mathrm{Tb}$ in $0.2 \%$ of samples collected from slaughterhouses. Post-mortem examination, carried out by sanitary inspection services, provides only a presumptive diagnosis, since the examination constitutes a simple macroscopic analysis of the lesions encountered (Brasil 2001). In this sense, the microbiological methods as diagnostic procedures should complement post-mortem inspection (Andrade et al. 1991, Corner 1994, Liébana et al. 1995, Pinto et al. 2002).

Due to dysgonic and very slow growth, the identification of $M$. bovis by conventional biochemical methods is cumbersome and time-consuming. Direct use of polymerase

Financial support: Fundect

${ }^{+}$Corresponding author. E-mail: analudmv@ nin.ufms.br

${ }^{++}$Capes fellowship recipient

Received 15 December 2004

Accepted 27 September 2005 chain reaction (PCR) on biological samples enables diagnosis to be reached within $48 \mathrm{~h}$, but the presence of inhibitors in tissue samples could interfere with its performance (De Wit et al. 1990, Clarridge et al. 1993, Folgueira et al. 1993, Nolte et al. 1993, Liébana et al. 1995, Kirshner et al. 1996, Mangiapan et al. 1996). In this sense PCR from culture is more sensible (Sakamoto 1997). In 1995, Rodriguez et al. described a pair of primers for the amplification of a 500-bp DNA fragment specific for M. bovis, that was applied to study $M$. bovis infection in cattle (Sakamoto 1997, Rodriguez et al. 1999, Sechi et al. 2000). The genotypic detection of the gene encoding for the $65-\mathrm{kDa}$ protein using two restriction enzymes by PCR-restriction enzyme pattern analysis (PRA) (Telenti et al. 1993) is a reliable assay to identify species that belong to the $M y$ cobacterium genus, although this technique fails to differentiate $M$. bovis from $M$. tuberculosis. Due to a few number of $M$. bovis research in Brazil, mainly in Mato Grosso do Sul, the aim of this study was to carry out the molecular identification of acid-fast bacilli isolated from tissue samples taken from carcasses of bovines during post-mortem inspection.

A total of 72 samples of tuberculosis-suspected lesions were collected from five slaughterhouses in Mato Grosso do Sul from May to November 2003. Lymph nodes lesions and lung fragments were extracted from the carcasses during the slaughter inspection carried out by veterinarians of Federal Inspection Service. All samples were kept in ice on their way to the laboratory. The pathological samples were initially decontaminated with the Petroff method (Brasil 1994) and cultured on Stonebrink medium for 3 months at $37^{\circ} \mathrm{C}$. Colonies positive for acidfast bacilli (AFB) by Ziehl-Neelsen technique were sub- 
mitted to molecular identification by PCR (Rodriguez et al. 1999), and PRA (Telenti et al. 1993). Briefly, for PCR identification, the mycobacterial DNA was extracted by three time boiling/freezing proceeding and amplified using the primers Jb21 (5'-TCGTCCGCTGATGCAAGTGC-3') and Jb22 (5'-CGTCCGCTGACCTCAAGAAG-3') described by Rodriguez et al. (1995). For PRA, primers for hsp65 gene Tb11 (5'-ACCAACGAT GGTGTGTCCAT-3') and Tb12 (5'CTTGTCGAACCGCATACCCT-3') were used for amplification of four samples negative for PCR. The amplicons were fragmented by the restriction enzymes BstE II and Hae III. The length of restriction fragments were estimated with the computer software ImageMaster VDS, version 3.0 for Windows 95,NT (Pharmacia Biotech), and the patterns obtained were evaluated using the Prasite (http:// app.chuv.ch/prasite/index.html).

Mycobacteria were isolated from 17 (23.6\%) of 72 lesion samples. All the isolates were confirmed as being AFB. Among the isolates, by PCR, 500-bp fragments suggestive of M. bovis were present in $13(76.4 \%)$ samples (Fig. 1). From four isolates (23.6\%) that lacked the 500-bp, PRA identified two as M. tuberculosis complex (MTC), and two as nontuberculous mycobacteria (M. fortuitum type 1) (Fig. 2, Table).

These results demonstrate that two isolates identified as MTC by PRA may also be $M$. bovis that did not amplify by species specific primers (JB21/JB22). In 121 culture samples from Argentina, México, and Colombia, Rodriguez et al. (1999) obtained $100 \%$ of data concordance between the microbiological method and PCR with primers JB21/ JB22. However, Sechi et al. (2000) found that in 13.3\% (4/ 30) of samples $M$. bovis failed to be identified when PCR was conducted with the same primers. By using the primers internalized in the insertion sequence IS6110, Sechi et al. (2000) confirmed that the isolates that remained uni-

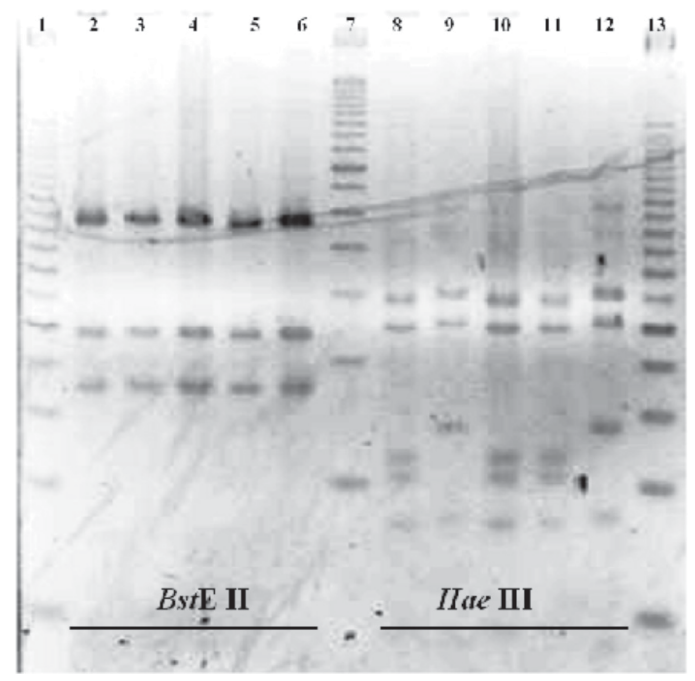

Fig. 2: polymerase chain reaction (PCR)-restriction enzyme pattern analysis genotype of four mycobacteria strains that did not amplified with PCR using primers Jb21 and Jb22. Columns 2, 8: standard Mycobacterium fortuitum type 1; columns 3, 6, 9, 12: M. tuberculosis complex; columns 4, 5, 10, 11: M. fortuitum type 1; columns 1, 13: ladder $25 \mathrm{bp}$; column 7: ladder $50 \mathrm{bp}$.

TABLE

Polymerase chain reaction (PCR)-restriction enzyme pattern analysis genotype of four mycobacteria strains that did not amplified with PCR using primers Jb21 and Jb22

\begin{tabular}{lll}
\hline Mycobacterium & BstEII & HaeIII \\
\hline M. tuberculosis complex & $235 / 115 / 85$ & $150 / 125 / 70$ \\
M. tuberculosis complex & $235 / 115 / 85$ & $150 / 125 / 70$ \\
M. fortuitum type 1 & $235 / 115 / 85$ & $145 / 120 / 60 / 55$ \\
M. fortuitum type 1 & $235 / 115 / 85$ & $145 / 120 / 60 / 55$ \\
\hline
\end{tabular}

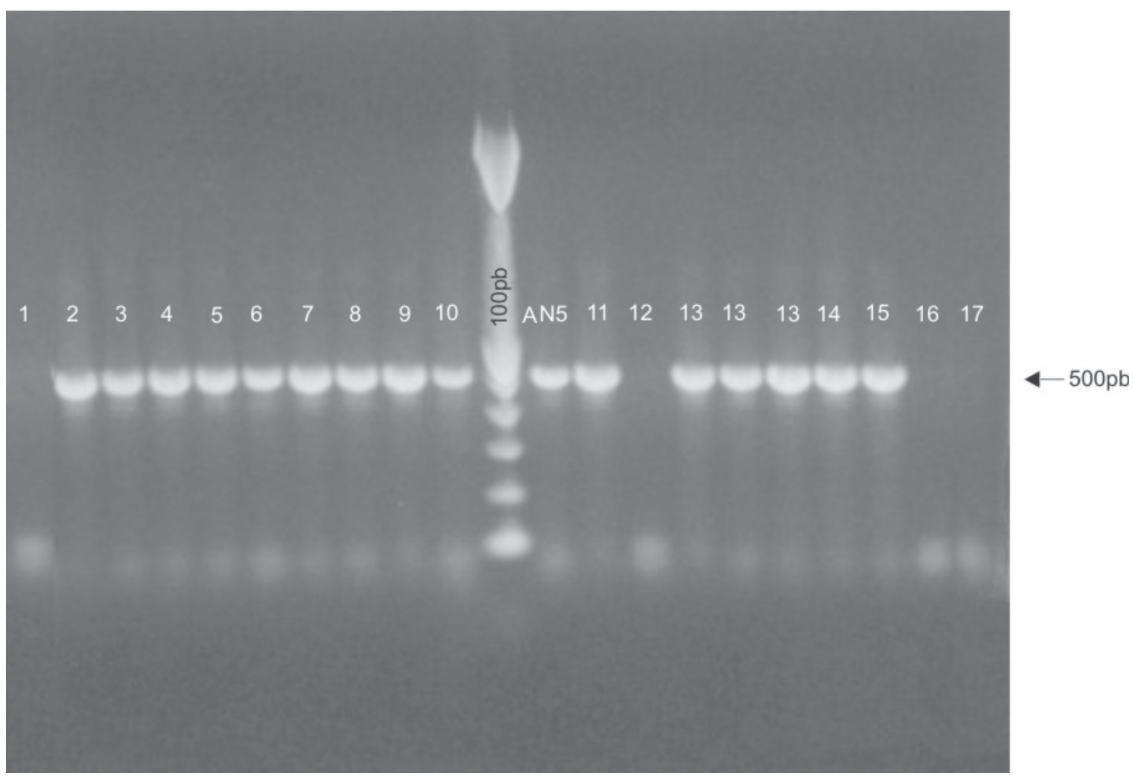

Fig. 1: band profile of polymerase chain reaction assay of material from acid-fast bacilli colonies. Central columns: 100-bp marker and AN-5 Mycobacterium bovis standard sample; columns 2, 3, 4, 5, 6, 7, 8, 9, 10, 11, 13, 14, 15 amplified 500-bp fragment; columns 1, 12, 16,17 did not amplify. 
dentified by JB21/JB22 belonged to the MTC. These data can justify our negative results in $11.8 \%(2 / 17)$ of the isolates. Possibly, these isolates lacked a target for primers JB21/JB22. The use of a single molecular technique can produce false negative results, hence the need for applying more than one type of technique. Leite et al. (2003), using culture and identification by PCR and RFLP-PCR, found $68.2 \%$ of positivity for M. bovis in pathological bovine and bubaline samples.

The efficiency of the culture used as a first criterion for M. bovis identification was low (23.6\%). One possible explanation is that some tissues may contain only a few live bacteria and even a short delay in getting tissues to the laboratory diagnosis might reduce chances for a successful bacterial isolation. Another reason is the sensitivity of the mycobacteria to the sodium hydroxide used in the method of Petroff (CPZ 1988, Miller et al. 2002).

The results show that the PCR method used in the present work is quick and reproductive, reliable for the study of slow-growing mycobacteria, particularly in cultures where the small number of bacilli hinders identification by classical methods. Although the presence of $M$. bovis was confirmed in only 13 out of 72 samples, the results indicate that the slaughter cattle from Mato Grosso do Sul is a source of infection by M. bovis that can be accounted for the disease in other animal species as well as for the zoonoses occurring in this Brazilian state.

The additional Mycobacterium specie identified from pathologic specimens, M. fortuitum is considered pathogenic and cause a variety of disease in humans (Wollinsky 1992). In a national surveillance of mycobacterioses, from 500 cultures of nontuberculous mycobacteria, $M$. fortuitum was identified in $10.8 \%$ of the cases and represented one of the most frequently identified species (Barretos \& Campos 2002).

In conclusion, the presence of $M$. bovis and other potential pathogenic mycobacteria in livestock tissue, suggests that humans may be exposed to these organisms as result of contact and ingestion.

\section{REFERENCES}

Andrade GB, Riet-Correa F, Mielke PV, Méndez MC, Schild AL 1991. Estudo histológico e isolamento de micobactérias de lesões similares a tuberculose em bovinos no Rio Grande do Sul. Pesq Vet Bras 11: 81-86.

Barretos AMW, Campos CED 2002. Micobactérias não tuberculosas no Brasil. Bol Pneumol Sanit 8: 23-31.

Brasil 1994. Manual de Bacteriologia da Tuberculose, Centro de Referência Professor Hélio Fraga, Fundação Nacional de Saúde, Ministério da Saúde, Rio de Janeiro, 114 pp.

Brasil 2001. Ministério da Agricultura, Pecuária e Abastecimento. Regulamento Técnico do Programa Nacional de Controle e Erradicação da Brucelose e Tuberculose, Instrução normativa DAS 6/2001.

Brasil 2003. Manual Técnico do Programa Nacional de Controle e Erradicação da Brucelose e Tuberculose, Ministéio da Saúde, Rio de Janeiro, 121 pp.

Clarridge JE, Shawar RM, Shinnick TM, Plikaytis BB 1993. Large-scale use of polymerase chain reaction for detection of Mycobacterium tuberculosis in a routine mycobacteriol- ogy laboratory. J Clin Microbiol 31: 2049-2056.

Corner LA 1994. Post-mortem diagnosis of Mycobacterium bovis infection in cattle. Vet Microbiol 40: 53-63.

CPZ-Centro Panamericano de Zoonosis 1988. Manual de Normas y Procedimientos Técnicos para la Bacteriologia de la Tuberculosis III. Sensibilidad del Mycobacterium tuberculosis a las Drogas. La Identificación de Micobactérias, Buenos Aires, 29 pp.

De Wit D, Steyn L, Shoemaker S, Sogin M 1990. Direct detection of Mycobacterium tuberculosis in clinical specimens by DNA amplification. J Clin Microbiol 28: 2437-2441.

Folgueira L, Delgado R, Palenque E, Noruega AR 1993. Detection of Mycobacterium tuberculosis DNA in clinical samples by using a polymerase reaction. J Clin Microbiol 31: 10191021.

Kirschner P, Rosenau J, Springer B, Teschner K, Feldmann K, Bottger EC 1996. Diagnosis of mycobacterial infections by nucleic acid amplification: 18 -month prospective study. $J$ Clin Microbiol 34: 304-312.

Leite CQF, Anno IS, Leite RSA, Roxo E, Morlock GL, Cooksey RC 2003. Isolation and identification of mycobacteria from livestock specimens and milk obtained in Brazil. Mem Inst Oswaldo Cruz 98: 319-323.

Liébana E, Aranaz A, Mateos A, Vilafranca M, Gómez-Mampaso E, Tercero JC, Alemany J, Suarez G, Domingo M, Dominguez L 1995. Simple and rapid detection of Mycobacterium tuberculosis complex organisms in bovine tissue samples by PCR. Eur J Clin Microbiol Infect Dis 33: 33-36.

Mangiapan G, Vokurka M, Shouls L, Cadranel J, Lecossier D, Van Embden J, Hance AJ 1996. Sequence capture-PCR improves detection of mycobacterial DNA in clinical specimens. J Clinical Microbiol 34: 1209-1215.

Miller JM, Jenny AL, Payeur JB 2002. Polymerase chain reaction detection of Mycobacterium tuberculosis complex and Mycobacterium avium organisms in formalin-fixed tissues from culture-negative ruminants. Vet Microbiol 87: 15-23.

Nolte FS, Metchock B, McGowan Jr JE, Edwards A, Okwumabua O, Thurmond C, Mitchell PS, Plikaytis B, Shinnick T 1993. Direct detection of Mycobacterium tuberculosis in sputum by polymerase chain reaction and DNA hybridization. J Clin Microbiol 31: 1777-1782.

Parreiras PM, Lobato FC, Alencar AP, Figueiredo T, Gomes HM, Boechat N, Lage AP, Assis RA, Pereira MA, Souza PR, Mota PM, Suffys PN 2004. Drug susceptibility of Brazilian strains of Mycobacterium bovis using traditional and molecular techniques. Mem Inst Oswaldo Cruz 99: 749752.

Pinto PSA, Faria JE, Viloria MIV, Bevilacqua PD 2002. Exame microbiológico da tuberculose como subsídio à inspeção post-mortem de bovinos. Rev Bras Saúde e Prod Anim 3: 10-15.

Rodriguez JG, Fissanoti JC, Del Portillo P, Patarroyo ME, Romano MI, Cataldi A 1999. Amplification of a 500-basepair fragment from cultured isolates of Mycobacterium bovis. Eur J Clin Microbiol Infect Dis 37: 2330-2332.

Rodriguez JG, Mejia GA, Del Protillo P, Patarroyo ME, Murillo LA 1995. Species-specific identification of Mycobacterium bovis by PCR. Microbiology 141: 2131-2138.

Sakamoto SM 1997. Detecção e Identificação de Mycobacte- 
rium bovis pela Reação de Polimerase em Cadeia (PCR), MSc Thesis, FMVZ, São Paulo, 43 pp.

Schenk MAM, Schenck JAP 1982. Prevalência de tuberculose, cisticercose e hidatidose em bovinos abatidos nos matadouros frigoríficos do estado de Mato Grosso do Sul, Brasil (1974/1979). A Hora Veterinária 1: 28-31.

Sechi LA, Dupre I, Leori G, Fadda G, Zanetti S 2000. Distribution of a specific 500-base-pair fragment in Mycobacterium bovis isolates from Sardinian cattle. J Clin Microbiol 38: 3837-3839.
Telenti A, Marchesi F, Balz M, Bally F, Bottger EC, Bodmer T 1993. Rapid identification of mycobacteria to the species level by polymerase chain reaction and restriction enzyme analysis. J Clin Microbiol 31: 175-178.

WHO-World Health Organization 1993. Report of the WHO meeting of zoonotic tuberculosis (Mycobacterium bovis) Technical Note, Geneva, 27 pp.

Wolinsky E 1992. Mycobacterial diseases other than tuberculosis. Clin Infect Dis 15: 1-12. 